\title{
Effect of Azadirachta indica supplemented feed on growth performance of Labeo rohita
}

Namrah Nazeer ${ }^{1}$, Amara Akhtar ${ }^{1}$, Muhammad Ashfaq ${ }^{2}$, Iqra Aslam ${ }^{1}$, Muhammad Zeeshan Mansha ${ }^{3 *}$, Kamran Ikram, Hafiz Muhammad Aatif $^{3}$, Hafiz Muhammad Usman Aslam ${ }^{5}$, Yasir Ali $^{3}$ and Qamar uz Zaman $^{6}$

1. Department of Zoology, Wildlife and Fisheries, University of Agriculture, Faisalabad-Pakistan

2. Department of Entomology, Faculty of Agriculture, University of Agriculture, Faisalabad-Pakistan

3. Department of Plant Pathology, College of Agriculture, Bahauddin Zakariya University, Bahadur Sub Campus, Layyah, Punjab-Pakistan

4. Department of Agricultural Engineering, Khwaja Fareed University of Engineering and Information Technology,

Rahim Yar Khan-Pakistan

5. Pest warning and Quality control of Pesticides, Punjab-Pakistan

6. Department of Environmental Sciences, The University of Lahore, Lahore-Pakistan

*Corresponding author's email: mianzeeshan121@gmail.com

\section{Citation}

Namrah Nazeer, Amara Akhtar, Muhammad Ashfaq, Iqra Aslam, Muhammad Zeeshan Mansha, Kamran Ikram, Hafiz Muhammad Aatif, Hafiz Muhammad Usman Aslam, Yasir Ali and Qamar uz Zaman. Effect of Azadirachta indica supplemented feed on growth performance of Labeo rohita. Pure and Applied Biology. Vol. 10, Issue 1, pp115-123. http://dx.doi.org/10.19045/bspab.2021.100013

\begin{tabular}{llll}
\hline \hline Received: 05/05/2020 & Revised: 18/08/2020 & Accepted: 24/08/2020 & Online First: 15/09/2020 \\
\hline
\end{tabular}

\section{Abstract}

Effect of neem (Azadirachta indica) on the growth of Rohu (Labeo rohita) was investigated under lab conditions in the Department of Zoology, University of Agriculture Faisalabad. Experiment was performed for twelve-fortnights with three replicates. Fingerlings of L. rohita were acclimatized for one week in glass aquarium at reference diet before initiating the trial. $\mathrm{T}_{1}$ reference diet was administered to control group of fish without neem supplement but treated fish groups $T_{2}, T_{3}$ and $T_{4}$ were administered with 5,10 and $15 \mathrm{~g} / 1000 \mathrm{~g}$ test neem supplemented diet respectively. Growth parameters including total body weight, total body length, fork length, feed conversion ratio and specific growth concentration was calculated. Statistical analysis of growth parameters revealed that $15 \mathrm{~g} / 1000 \mathrm{~g}$ neem test diet showed highly significant $(p<0.01)$ gain in body weight $(11 \mathrm{~g})$, total body length $(9.7 \mathrm{~cm})$, fork length $(3.6 \mathrm{~cm})$ and specific growth concentrations (0.43) of $L$. rohita as compared to other diet groups but at $5 \mathrm{~g} / 1000 \mathrm{~g}$ test diet of neem showed maximum (2.75) mean value of feed conversion ratio. Neem (Azadirachta indica) is a naturally occurring medicinal herb having a lot of bioactive and biosafety compound that acts as growth enhancer, appetite stimulator and immunomodulator against infectious pathogens. The impact of current study is that higher concentration of neem supplemented feed effectively leads to higher growth of fish's body parameters such as total body weight, total body length, fork length as well as feed conversion ratio. Keywords: Feed conversion ratio; Fork length; Specific growth concentrations; Supplemented diet; Total body weight 


\section{Introduction}

Aquaculture is the biggest source of earning because of fast growing food production sector in the world $[1,2]$. In aquaculture, the continuous increasing trend of fish culturing has increased its demand as pivotal component for the health of animals in industry [3, 4]. Nutrition in fish diet promotes growth, maintain health of aquatic species of fish to meet the demand of human consumption and enhance activities of immune system to create resistance against diseased pathogens [5]. The danger of food shortage can be minimized by potential of healthy fish as it provides high quality protein, minerals and fatty acids to animal industry [6].

Labeo rohita is commonly well known as Rohu that is cultivated on commercial scale in Asia. Rohu gives approximately 35\% contribution to major carp production as it is cultural and abundantly present in Asian continent [7]. Labeo rohita is a vital source of animal protein, mineral, beneficial fat contents, vitamin and essential amino acid that provide healthy diet to animal industry [8].

Due to poor management and non-hygienic conditions of aquaculture, fish breeding leads to higher mortality [9].Vaccination is much more expensive for producer of fish aquaculture or may not be feasible for all diseased species of fish [10, 11]. Plants sources are the best alternative because of lower phosphorus contents, no harmful growth depressing entities, low cost and easy availability [12].

Neem (Azadirachta indica) is a naturally occurring medicinal herb having a lot of bioactive and biosafety compounds that acts as growth enhancer, immunostimulant to activate the activity of immune system, antistressor, antifungal, antiviral and anticancerous agent [13-16]. Neem is known as well defined "Village Dispensary" in India that is an essential part and parcel of human society to control fish diseases and gives valuable growth concentrations and immunity to fish farms [17 -19].

The objective of the present study was to evaluate the medicinal effects of Azadirachta indica supplemented feed on growth performance in Labeo rohita to meet the demand of health status of fish and human consumption by increasing growth rate as well as immunity of fish.

\section{Materials and Methods}

\section{Fish collection}

Fish seeds was collected from Government Fish Seed Hatchery, Satiana Road, Faisalabad and transferred to Fisheries Research Farm, Department of Zoology, Wildlife and Fisheries, University of Agriculture, Faisalabad, Pakistan. This laboratorial work was settled for the period of six months from Dec, 2018 to May, 2019. Fingerlings of Labeo rohita were acclimatized for one week in glass aquarium at reference diet, $12 \mathrm{~h}$ light/dark period, continuous aeration and water quality parameters at standard $\mathrm{pH}$ value 7, Temperature $\quad 26 \pm 2{ }^{\circ} \mathrm{C}$, DO $5.0 \pm 0.3 \mathrm{mg} / \mathrm{L}$ before initiating the trial.

\section{Neem supplemented diet preparation}

Commercial diet for fishes was taken in the form of small pellet and grinded in powder form with the help of electric grinder. Leaves of neem plant were taken from surrounding area of Department of Zoology, Wildlife and Fisheries and aerated at room temperature for $48 \mathrm{~h}$. These dried leaves were grinded with the help of pestle and mortar. Supplemented diet was prepared by the addition of commercial diet in different concentrations of neem powder mixture. $T_{1}$ reference diet was without neem diet and considered as control diet. $\mathrm{T}_{2}, \mathrm{~T}_{3}$ and $\mathrm{T}_{4}$ test diets were prepared by adding neem $5 / 1000$, $10 / 1000$ and $15 \mathrm{~g} / 1000 \mathrm{~g}$ into commercial diet. Linear formulation method was followed during reference and test diet preparation (Table 1). 
Table 1. Ingredients of neem supplemented feed

\begin{tabular}{|c|c|c|c|c|c|c|}
\hline Ingredients & $\begin{array}{c}\text { Fish meal } \\
(\mathbf{g} / \mathbf{k g})\end{array}$ & $\begin{array}{c}\text { Soya oil } \\
(\mathbf{g} / \mathbf{k g})\end{array}$ & $\begin{array}{c}\text { Gluten } \\
(\mathbf{g} / \mathbf{k g})\end{array}$ & $\begin{array}{c}\text { Premix } \\
(\mathbf{g} / \mathbf{k g})\end{array}$ & $\begin{array}{c}\text { Rice Polish } \\
(\mathbf{g} / \mathbf{k g})\end{array}$ & $\begin{array}{c}\text { Neem } \\
\mathbf{( g / k g})\end{array}$ \\
\hline $\mathbf{T}_{\mathbf{1}}$ (control group) & 300 & 20 & 320 & 30 & 330 & 0 \\
\hline $\mathbf{T}_{\mathbf{2}}$ & 299 & 19 & 319 & 29 & 329 & 5 \\
\hline $\mathbf{T}_{\mathbf{3}}$ & 298 & 18 & 318 & 28 & 328 & 10 \\
\hline $\mathbf{T}_{\mathbf{4}}$ & 297 & 17 & 317 & 27 & 327 & 15 \\
\hline
\end{tabular}

\section{Feeding protocol}

Initial weight $(\mathrm{g})$ and length $(\mathrm{cm})$ of fish samples were measured and transferred to glass aquarium covered with nylon net and plastic clip in Laboratory after acclimatization process. Three replicates of fish fingerling were kept in each aquarium. The water was filled in each aquarium up to $65 \mathrm{~L}$ or $3 / 4$ part of aquarium. Water of all aquariums was recycled once in a day. Diet was given to fish at the concentration of $6 \%$ of their body weight.

\section{Growth parameters}

Growth parameters of each aquarium such as total body weight (g), total body length $(\mathrm{cm})$ and fork length $(\mathrm{cm})$, FCR (feed conversion ratio) and SGR (specific growth concentrations) were measured fortnightly and compared with controlled fish samples. To calculate FCR (feed conversion ratio) and SGR (specific growth concentrations), the values percent weight gain $(\mathrm{g})$, initial body weight of last fortnight, final body weight of that fortnight was noted.

Weight gain of fish was calculated by formula [20].

Specific growth concentrations and feed conversion ratio were calculated as

Feed Conservation Ration $=\frac{\mathrm{F}}{\mathrm{W}_{\mathrm{f}}-\mathrm{W}_{\mathrm{i}}}$

Where

$\mathrm{F}$, indicates the weight of supplied feed to Rohu
$\mathrm{W}_{\mathrm{f}}$, value indicates the final body weight of fish at present fortnight

$\mathrm{W}_{\mathrm{i}}$, value indicates the initial body weight of fish at last fortnight.

\section{Statistical analysis of data}

The statistical analysis of recorded data was done by using Micro Computer IM-PC. Two Factor Factorial Analysis of Variance was used to analyze data of growth parameters (body weight, total length, fork length, FCR and SGR).The analysis of all parameters was done to finds Significant or nonsignificant differences among parameters along with fortnights. For the computation of these data Minitab software was used.

\section{Results}

\section{Body weight (g)}

Results showed that highest body weight was observed in $\mathrm{T}_{4}$ diet. The maximum and minimum weight gain (g) for $\mathrm{T}_{4}$ test diet was $2.4 \mathrm{~g}$ and $0.3 \mathrm{~g}$ in $9^{\text {th }}$ fortnight (April) and $1^{\text {st }}$ fortnight (December). The maximum and minimum weight gain $(\mathrm{g})$ for $\mathrm{T}_{1}$ reference diet was $0.6 \mathrm{~g}$ and $0.1 \mathrm{~g}$ in $9^{\text {th }}$ fortnight (April) and $1^{\text {st }}$ fortnight (December), respectively. The maximum and minimum weight gain (g) for $\mathrm{T}_{2}$ test diet was $0.8 \mathrm{~g}$ and $0.1 \mathrm{~g}$ in $9^{\text {th }}$ fortnight (April) and $1^{\text {st }}$ fortnight (December), respectively. The maximum and minimum weight gain (g) for $\mathrm{T}_{3}$ test diet was $1.4 \mathrm{~g}$ and $0.2 \mathrm{~g}$ in $9^{\text {th }}$ fortnight (April) and $1^{\text {st }}$ fortnight (December) respectively (Fig. 1). 


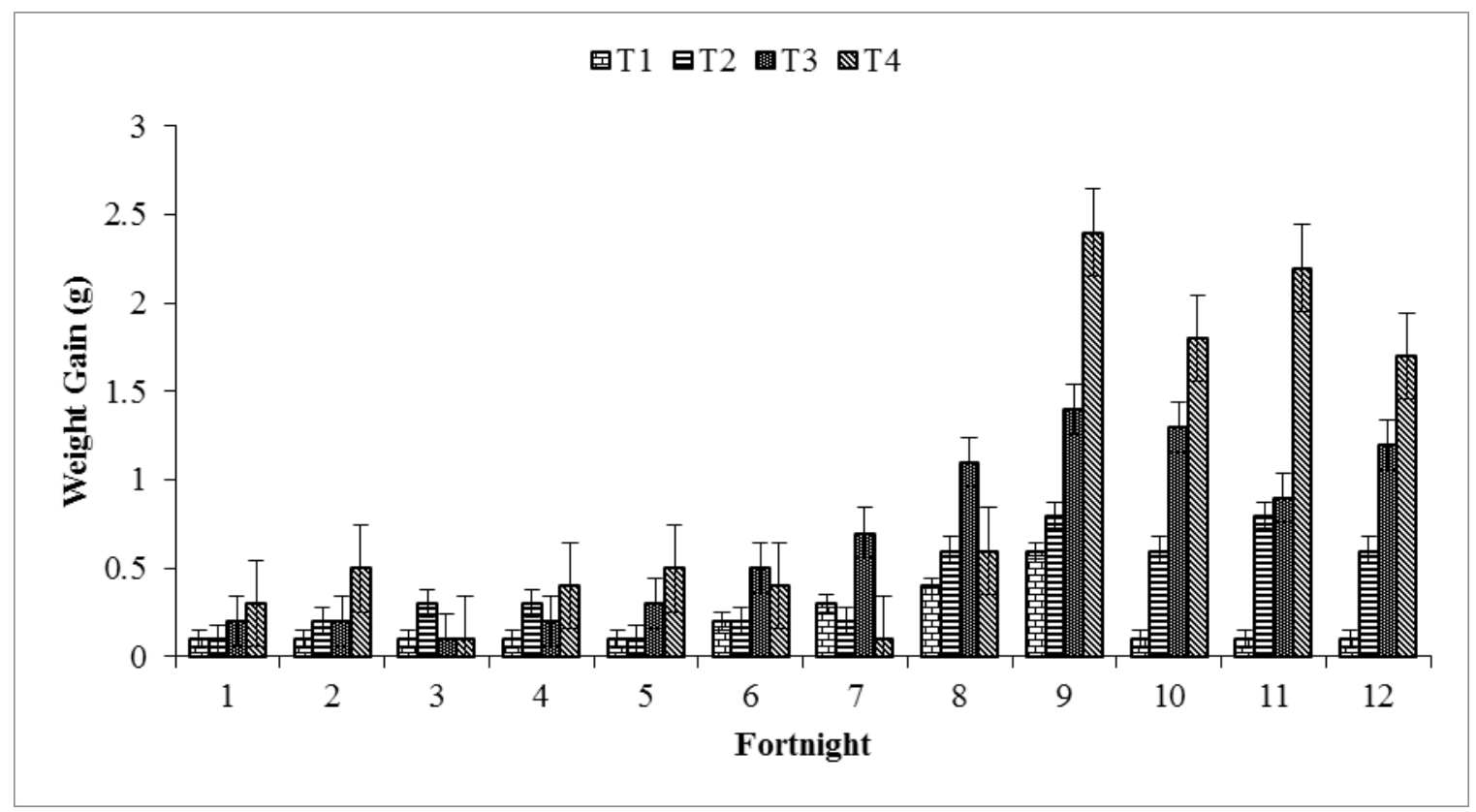

Figure 1. Fortnightly increase in average body weight (g) of Labeo rohita feed on reference diet and three test diets

\section{Body length (cm)}

Results showed that highest body length was observed in $\mathrm{T}_{4}$ diet. The maximum and minimum length gain $(\mathrm{cm})$ for $\mathrm{T}_{4}$ test diet was $2.2 \mathrm{~cm}$ and $0.2 \mathrm{~cm}$ in $8^{\text {th }}$ fortnight (March) and $1^{\text {st }}$ fortnight (December). The maximum and minimum length gain $(\mathrm{cm})$ for $\mathrm{T}_{1}$ reference diet was $0.3 \mathrm{~cm}$ and $0.1 \mathrm{~cm}$ in $8^{\text {th }}$ fortnight $\left(\right.$ March) and $1^{\text {st }}$ fortnight (December), respectively. The maximum and minimum length gain $(\mathrm{cm})$ for $\mathrm{T}_{2}$ test diet was $0.6 \mathrm{~cm}$ and $0.1 \mathrm{~cm}$ in $8^{\text {th }}$ fortnight (March) and $1^{\text {st }}$ fortnight (December), respectively. The maximum and minimum length gain $(\mathrm{cm})$ for $T_{3}$ test diet was $0.7 \mathrm{~cm}$ and $0.1 \mathrm{~cm}$ in $8^{\text {th }}$ fortnight (March) and $1^{\text {st }}$ fortnight (December) respectively (Fig. 2).

\section{Fork length (cm)}

Results showed that highest fork length gain was observed in diet $\mathrm{T}_{4}$. The maximum and minimum fork length gain $(\mathrm{cm})$ for $\mathrm{T}_{4}$ test diet was $0.7 \mathrm{~cm}$ and $0.1 \mathrm{~cm}$ in $9^{\text {th }}$ fortnight (April) and $1^{\text {st }}$ fortnight (December). The maximum and minimum fork length gain (cm) for $\mathrm{T}_{2}$ test diet was $0.4 \mathrm{~cm}$ and $0.1 \mathrm{~cm}$ in $9^{\text {th }}$ fortnight (April) and $1^{\text {st }}$ fortnight (December), respectively. The maximum and minimum fork length gain $(\mathrm{cm})$ for $\mathrm{T}_{3}$ test diet was $0.5 \mathrm{~cm}$ and $0.1 \mathrm{~cm}$ in $9^{\text {th }}$ fortnight (April) and $1^{\text {st }}$ fortnight (December), respectively (Fig. 3).

\section{Feed conversion ratio}

Results showed that feed conversion ratio was observed maximum in diet $\mathrm{T}_{2}$. The maximum and minimum feed conversion ratio for $\mathrm{T}_{2}$ test diet was 6.6 and 0.91 in $5^{\text {th }}$ fortnight (February) and $9^{\text {th }}$ fortnight (April). The maximum and minimum feed conversion ratio for $T_{1}$ reference diet was 3.0 and 0.42 in $12^{\text {th }}$ fortnight (May) and $9^{\text {th }}$ fortnight (April), respectively. The maximum and minimum feed conversion ratio for $T_{3}$ test diet was 6.03 and 0.58 in $3^{\text {rd }}$ fortnight (January) and $9^{\text {th }}$ fortnight (April), respectively. The maximum and minimum feed conversion ratio for $\mathrm{T}_{4}$ test diet was 7.5 and 0.33 in $7^{\text {th }}$ fortnight (March) and $9^{\text {th }}$ fortnight (April), respectively (Fig. 4). 


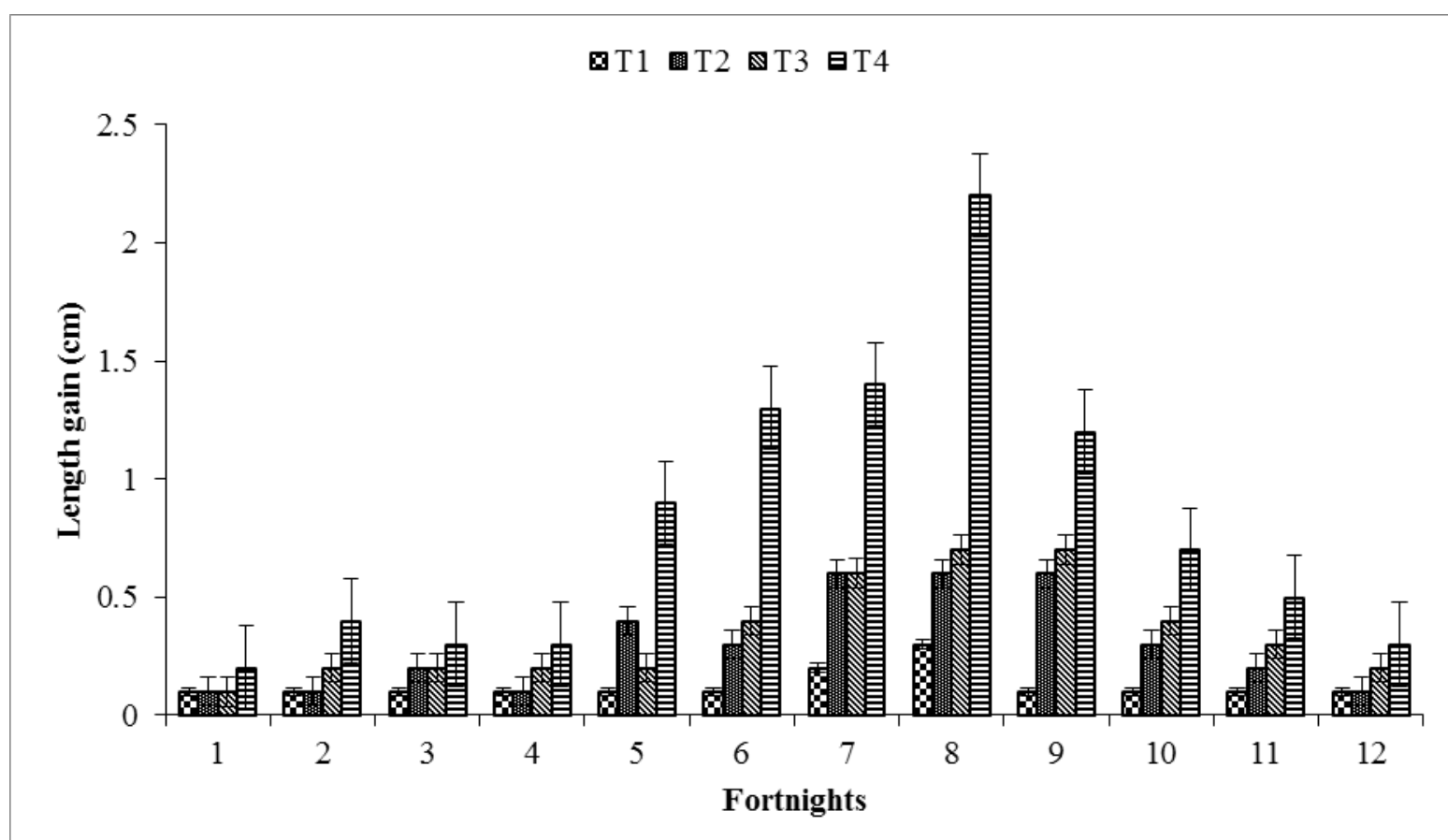

Figure 2. Fortnightly increase in average body length $(\mathrm{cm})$ of Labeo rohita feed on reference diet and three test diet

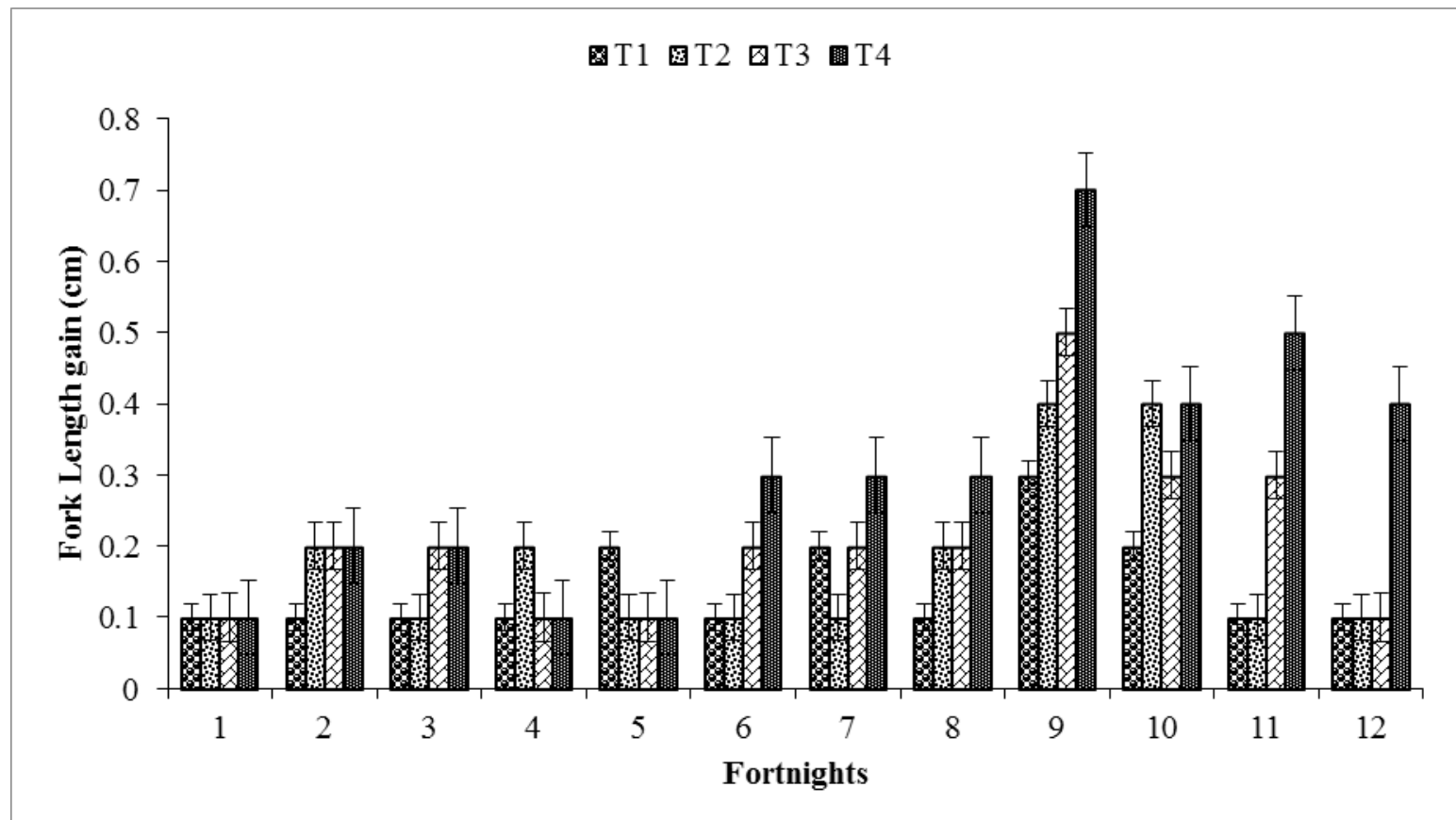

Figure 3. Fortnightly increase in average fork length $(\mathrm{cm})$ of Labeo rohita feed on reference diet and three test diets 


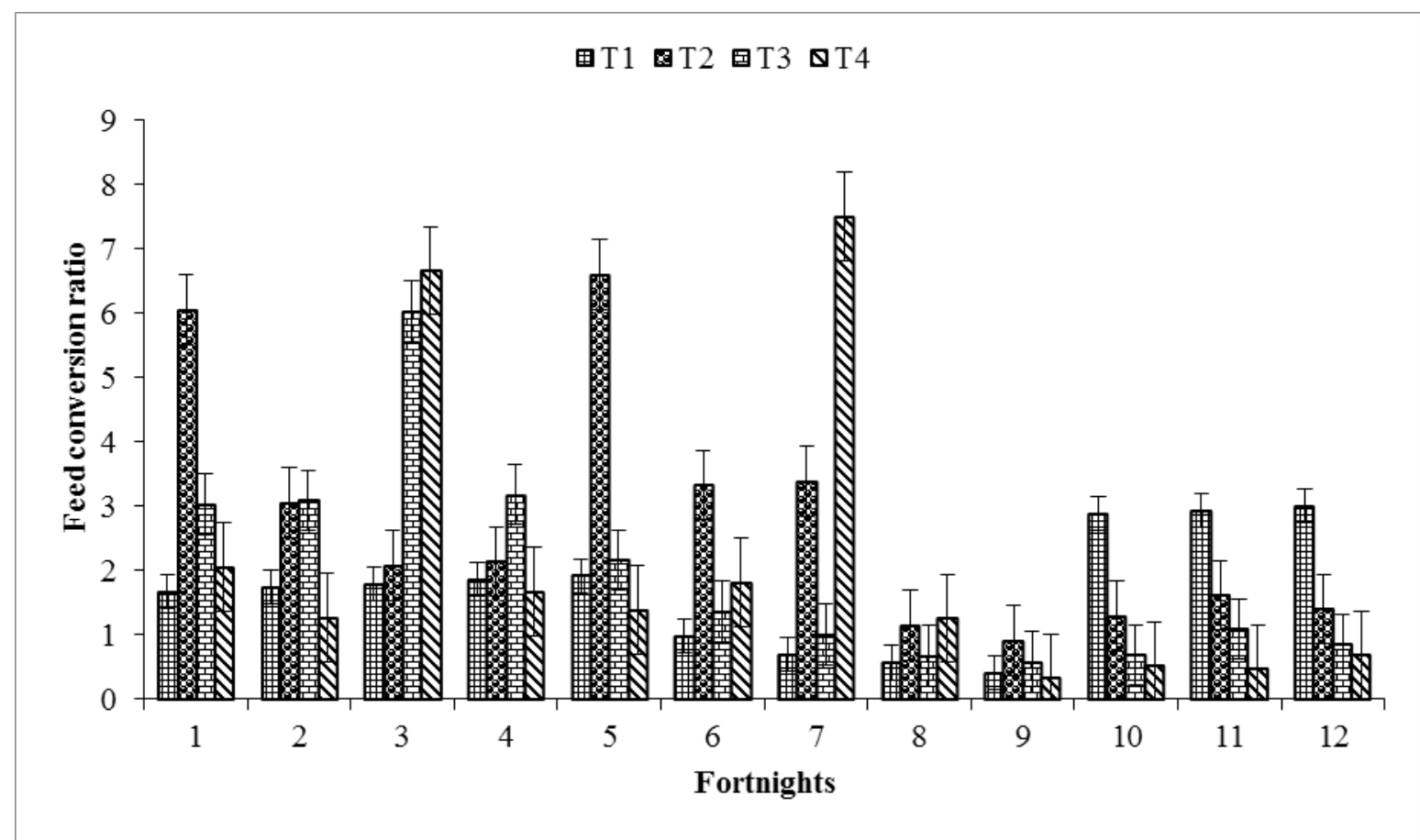

Figure 4. Fortnightly changes in feed conversion ratio of Labeo rohita feed on reference diet and three test diets

\section{Specific growth concentrations}

Results showed that mean value of specific growth concentrations was observed maximum in $\mathrm{T}_{4}$ diet. The maximum and minimum specific growth concentrations for $\mathrm{T}_{4}$ test diet was 1.19 and 0.05 in $9^{\text {th }}$ fortnight (April) and $7^{\text {th }}$ fortnight (March). The maximum and minimum specific growth concentrations for $\mathrm{T}_{1}$ reference diet was 0.95 and 0.14 in $9^{\text {th }}$ fortnight (April) and $11^{\text {th }}, 12^{\text {th }}$ fortnight (May). The maximum and minimum specific growth concentrations for $\mathrm{T}_{2}$ test diet was 0.45 and 0.06 in $9^{\text {th }}$ fortnight (April) and $5^{\text {th }}$ fortnight (February). The maximum and minimum specific growth concentrations for $\mathrm{T}_{3}$ test diet was 0.7 and 0.07 in $9^{\text {th }}$ fortnight (April) and $3^{\text {rd }}$ fortnight (January), respectively (Fig. 5).

\section{Discussion}

The aim of this study was to investigate the effect of neem (Azadirachta indica) on growth performance such as total body weight, total length, fork length, feed conversion ratio, Specific growth concentrations in Labeo rohita (Rohu). The growth of fish was directly proportional to concentrations of diet ratio i.e. higher growth of the fish by increase in the neem supplemented diet ratio. The highest growth concentrations as weight, length and fork length was achieved at higher diet ratio of neem $\left(\mathrm{T}_{4}\right)$ just as $10.3-21.3 \mathrm{~g}, 9.5-19.2 \mathrm{~cm}$ and $1.9-5.5 \mathrm{~cm}$ respectively, as compared to other diet ratio at $T_{2}, T_{3}$ test diets and $T_{1}$ reference diet. The inferences of current study are correlated with [21] who have administered fish with neem inoculated diet and found a great influence on growth parameters of fish along with increasing trend of neem concentration. This study showed the same enhancement trend of fish growth that was observed in our study.

A study conducted by Nya and Austin [22] to find out the effect of various diet ratio of ginger for 14 days on growth performance, reduction in mortality of rainbow trout. The results showed that ginger had significant effect on fish growth and immune response. The findings of this study concluded that by increasing the dose concentrations of any 
medicinal plant extract leads to the increase in growth of fish and their results are similar to our work that showed total body weight gain $(11 \mathrm{~g})$, total length gain $(9.7 \mathrm{~cm})$ and total fork length gain $(3.6 \mathrm{~cm})$ during six months period at test diet $\mathrm{T} 4(15 \mathrm{~g} / 1000 \mathrm{~g}$ neem).The verdicts of our study concluded that by increasing the dose concentrations (T4 test diet) of neem medicinal plant extract leads to the significant increase in growth parameters of fish at moderate physio-chemical parameters as compared to other test diets and reference diet similar to the study [23].

The inferences of our study described that highest mean of Specific Growth Concentrations 0.43 was noted for $\mathrm{T} 4$ test diet ( $15 \mathrm{~g}$ neem per $1000 \mathrm{~g}$ feed).The verdicts of the following study are agree with Basha et al., [24] who described that herbal Andrographis paniculata extract supplementary diet imparts stimulatory impact on specific growth concentrations and improved nonspecific immunity along with increase of disease resistant in $L$. rohita fingerlings against the infection of $A$. hydrophlia. The conclusions of our study described that highest Feed Conversion Ratio 2.75 was noted for $\mathrm{T}_{2}$ test diet $(15 \mathrm{~g}$ of neem per $\mathrm{kg}$ feed). Our study is in accordance with the study of [25] who accompanied an experiment to find out the influence of diet supplement of Astragalus radix, Lonicera japonica and also mixture of these plants tested for its effect on the growth performance and feed conversion ratio of juvenile pikeperch (Sander lucioperca). The whole data of 8 weeks was computed and concluded to highly significant $(p<0.05)$ results for growth parameters on herbal supplemented diet in accordance to our study.

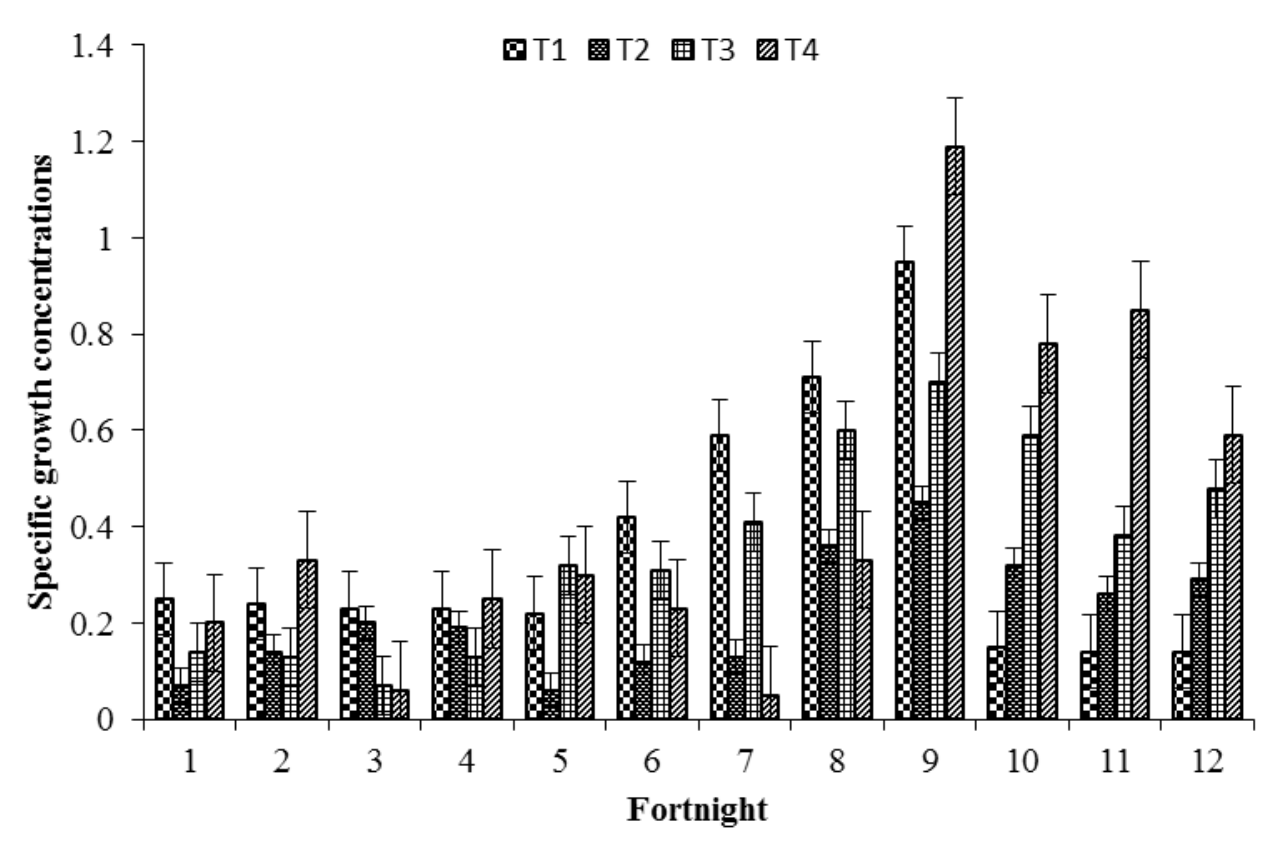

Figure 5. Fortnightly changes in specific growth concentrations of Labeo rohita feed on reference diet and three test diets

\section{Conclusion}

This study showed that growth performance of Labeo rohita directly related to the neem supplemented diet, showed enhancement trend and highly significant $(\mathrm{p}<0.05)$ results on growth parameters of Labeo rohita. With 
increase in neem supplemented diet all Growth parameters including total body weight, total body length, fork length, feed conversion ratio and specific growth concentration were increased. This study will be helpful for the aquaculture industry for the increase in the production of fishes. This study was conducted to evaluate the medicinal effects of Azadirachta indica supplemented feed on growth performance, health status and compensate demand of aquaculture industry by increasing growth rate as well as immunity of fish.

\section{Authors' contributions}

Conceived and designed the experiments: A Akhtar \& I Aslam, Performed the experiments: $\mathrm{N}$ Nazeer \& $\mathrm{M}$ Ashfaq, Analyzed the data: HM Aatif \& Y Ali, Contributed materials/ analysis/ tools: K Ikram \& HMU Aslam, Wrote the paper: MZ Mansha \& Q Zaman.

\section{Acknowledgements}

The Authors are grateful to Farzana Saleem and Hafiza Asima for helping in data collection and Nasir Ahmad of Fish Farm Management for the care of Labeo rohita.

\section{References}

1. Manoj VR \& Vasudevan N (2009). Functional options for sustainable shrimp aquaculture in India. $J$ Rev Fisheries Sci 17(3): 336-347.

2. Can E, Kizak V, Kayim M, Can SS, Kutlu B, Ates M, Kocabas M \& Demirtas N (2011). Nanotechnological applications in aquaculture-seafood industries and adverse effects of nanoparticles on environment. J Mater Sci Eng 5(5): 605-609.

3. Farre E, Gajda-Schrantz K, Kantiani L\& Barcelo D (2009). Ecotoxicity and analysis of nanomaterials in the aquatic environment. Anal Bioanal Chem 393(1): 81-95.

4. Kolkovski S \& Kolkovski J (2011). Herbal medicine in aquaculture. Int Aquafeed 14(2): 28-31.
5. Nargis A, Khatun M\& Talukder D (2011). Use of medical plants in the remedy of fish diseases. J Bang Res Publ 5(3): 192-195.

6. Belsare SS, Dhaker HS, Pawase AS, Joshi VR, Mohite SA \& Rathod RH (2018). Effects of dietary protein and lipid levels on growth, feed utilization and body composition in juvenile goldfish, Carassius auratus. Indian $J$ Anim Res 52(6): 875-881.

7. Khan MA, Jafri AK\& Chadha NK (2004). Growth and body composition of rahu, Labeo rohita (Hamilton), fed compound diet, winter feeding and rearing to marketable size. $J A p p l$ Ichthyol 20(4): 256-270.

8. Padmavathi P \& Veeraiah K (2009) Studies on the influence of Microcystis aeruginosa on the ecology and fish production of carp culture ponds. Afr $J$ Biotechnol 8(9): 1911-1918.

9. Cagirgan H (2009). Main sanitary problem and needs in Turkish fish farming. The use of veterinary drugs and vaccines in Mediterranean aquaculture.Option Medit 86:187-195.

10. Raa JG, Rorstad G, Engstad R \& Robertson B (1992). The use of immunostimulants to increase resistance of aquatic organisms to microbial infections. In Dis. Asian Aquacul 34(1): 39-50.

11. Sah U, Mukhiya U \& Pradhan N (2018). Effect of different types of feed on growth pattern of farmed rohu and genetically improved rohu, (Labeo rohita). Int J Fish Aquat Stud 6(6): 364-367

12. Rehman T, Asad F, Qureshi NA \& Iqbal S (2013). Effect of plant feed ingredients on the growth and body composition of Labeo rohita. Am J Life Sci 1(3): 125-129.

13. Sadeghian MM\& Mortazaienezhad F (2007). Investigation of compounds 
from Azadirachta indica (neem). Asian J Plant Sci 6(2): 444-445.

14. Mahabub-Uz-Zaman M, Ahmed NU, Akter R, Ahmed K, Aziz MSI\&Ahmed MS (2009). Studies on antiinflammatory, antinociceptive and antipyretic activities of ethanol extract of Azadirachta indica leaves.Bangladesh J Sci Ind Res 44(2): 199-206.

15. Ravikumar S, Selvan GP \& Gracelin AA (2010). Antimicrobial activity of medicinal plants along Kanyakumari coast. Tamil Nadu India. Afr J Basic Appl Sci 2(5-6): 153-157.

16. Maragathavalli S, Brindha S, Kaviyarasi NS, Annadurai B \& Gangwar SK (2012). Antimicrobial activity in leaf extract of neem (Azadirachta indica Linn.). Int J Sci Nat 3(1): 110-113.

17. Sahu S, Das BK, Mishra BK, Pradhan J \& Sarangi N (2007). Effect of Allium sativum on the immunity and survival of Labeo rohita infected with Aeromonas hydrophila. J Appl Ichthyol 23(1): 80-86.

18. Gupta SC, Prasad S, Tyagi AK, KunnumakkaraAB\& Aggarwal BB (2017). Neem (Azadirachta indica): An indian traditional panacea with modern molecular basis. Phytomedicine 34: 14-20.

19. Chutulo EC \& Chalannavar RK (2018). Endophytic mycoflora and their bioactive compounds from Azadirachta indica: a comprehensive review. J Fungi (Basel) 4(2): 42.

20. Akter N, Alam J, Jewel AS, Khatun S \& Akter S(2018). Evaluation of dietary metallic iron nanoparticles as feed additive for growth and physiology of Bagride catfish Clariasbatrachus (Linnaeus, 1758). Int J Fish Aqua Stud 6(3): 371-377.

21. Obaroh I, Nzeh G, Oguntoye S \& Bawa D (2014). Growth response of Oreochromisniloticus, fed crude extract of Azadirachta indica saponins. J Pharm Bio Sci 9(3): 44-48.

22. Nya EJ \& Austin B (2009). Use of dietary ginger, Zingiberofficinale Roscoe, as an immunostimulant to control Aeromonas hydrophila infections in rainbow trout, Oncorhynchusmykiss (Walbaum). J Fish Dis 32(11): 971-977.

23. Handeland SO, Imsland AK \& Stefansson SO (2008). The effect of temperature and fish size on growth, feed intake, food conversion efficiency and stomach evacuation concentrations of Atlantic salmon post-smolts. Aquacul 283(4): 36-42.

24. Basha KA, RamanRP, PrasadKP, KumarK, Nilavan E \&KumarS(2013). Effect of dietary supplemented andrographolide on growth, nonspecific immune parameters and resistance against Aeromonas hydrophila in Labeorohita (Hamilton). Fish and Shellfish Immun 35(5): 14331441.

25. Kowalska A, Demska-Zakęs K, Jeney $\mathrm{G}$ \& Jeney Z (2008). Effect of two medicinal herbs Astragalus radix and Lonicera japonica on the growth performance and body composition of juvenile pikeperch. $J$ Aquacult Res 39(11): 1149-1160. 